\title{
Semen may harbor HIV despite effective HAART: another piece in the puzzle
}

\author{
Philippe Halfon ${ }^{1}$, Claude Giorgetti ${ }^{2}$, Hacène Khiri ${ }^{1}$, Guillaume Pénaranda ${ }^{1 *}$, P Terriou², G Porcu-Buisson ${ }^{2}$, \\ Véronique Chabert-Orsini ${ }^{2}$
}

From $16^{\text {th }}$ International Symposium on HIV and Emerging Infectious Diseases

Marseille, France. 24-26 March 2010

\section{Background}

The aim of this study was to assess the prevalence of male patients with undetectable HIV levels in blood that had detectable levels of HIV in semen.

\section{Methods}

Three hundred and thirty-two HIV-1 infected men attending in a In vitro fertilization laboratory in Marseille (FRANCE) were included in the analysis with respect of the French law (absence of ongoing disease, CD 4 count $>200$ cells $/ \mathrm{mm} 3$, and stable HIV-1 RNA level). Overall, 394 paired blood and semen samples were provided between October 2001 and March 2009. The Cobas Taqman HIV-1 assay was used to quantify HIV-1 RNA in blood and in seminal plasma as previously described with a limit of quantification of 40 copies $/ \mathrm{ml}$ in blood and in seminal plasma.

\section{Results}

Overall, 272 (69\%) paired samples were concordant between blood plasma and seminal plasma for HIV-1 detection (inter-rater agreement $\mathrm{k}=0.12) ; 253(64 \%)$ samples were HIV-1 negative both in blood plasma and seminal plasma, and 19 (5\%) samples were HIV-1 positive both in blood plasma and seminal plasma. Overall, $122(31 \%)$ paired samples were discordant between blood plasma and seminal plasma for HIV-1 detection. Among these, 10 (3\%) seminal plasma samples had detectable HIV-1 RNA although blood viral load was undetectable for at least 6 months under antiretroviral treatment.

\footnotetext{
* Correspondence: g.penaranda@alphabio.fr

1 Laboratoire Alphabio, Marseille, France
}

\section{Discussion}

In conclusion, between $3 \%$ of patients with undetectable HIV levels in blood had detectable levels of HIV in semen. These data suggest that undetectable plasma HIV RNA means a lower risk of viral transmission through seminal fluid on a population level, but not necessarily at the level of the individual.

\section{Author details \\ 'Laboratoire Alphabio, Marseille, France. ${ }^{2}$ Institut Médical de Reproduction,} Marseille, France.

Published: 11 May 2010

doi:10.1186/1742-4690-7-S1-012

Cite this article as: Halfon et al: Semen may harbor HIV despite effective HAART: another piece in the puzzle. Retrovirology 2010 7(Suppl 1):012.
Submit your next manuscript to BioMed Central and take full advantage of:

- Convenient online submission

- Thorough peer review

- No space constraints or color figure charges

- Immediate publication on acceptance

- Inclusion in PubMed, CAS, Scopus and Google Scholar

- Research which is freely available for redistribution

Submit your manuscript at www.biomedcentral.com/submit 